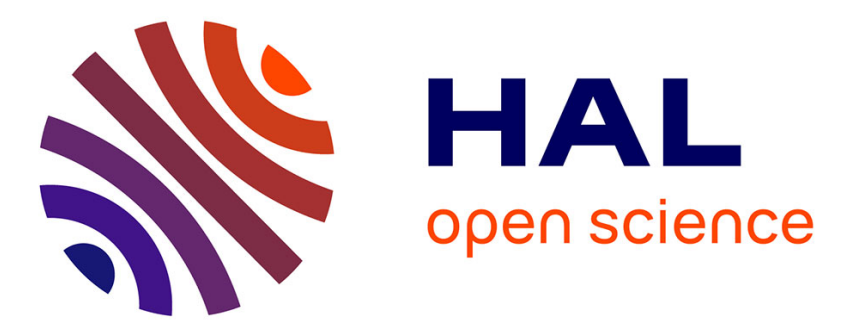

\title{
Toxicity of metal mixtures to the Pacific white shrimp postlarvae
}

\author{
M.G. Frías-Espericueta, D. Voltolina-Lobina, I. Osuna-López, G.
} Izaguirre-Fierro

\section{- To cite this version:}

M.G. Frías-Espericueta, D. Voltolina-Lobina, I. Osuna-López, G. Izaguirre-Fierro. Toxicity of metal mixtures to the Pacific white shrimp postlarvae. Marine Environmental Research, 2009, 68 (5), pp.223. 10.1016/j.marenvres.2009.06.011 . hal-00563088

\section{HAL Id: hal-00563088 \\ https://hal.science/hal-00563088}

Submitted on 4 Feb 2011

HAL is a multi-disciplinary open access archive for the deposit and dissemination of scientific research documents, whether they are published or not. The documents may come from teaching and research institutions in France or abroad, or from public or private research centers.
L'archive ouverte pluridisciplinaire HAL, est destinée au dépôt et à la diffusion de documents scientifiques de niveau recherche, publiés ou non, émanant des établissements d'enseignement et de recherche français ou étrangers, des laboratoires publics ou privés. 


\section{Accepted Manuscript}

Toxicity of metal mixtures to the Pacific white shrimp Litopenaeus vannamei postlarvae

M.G. Frías-Espericueta, D. Voltolina-Lobina, I. Osuna-López, G. IzaguirreFierro

PII:

S0141-1136(09)00081-6

DOI: 10.1016/j.marenvres.2009.06.011

Reference:

MERE 3350

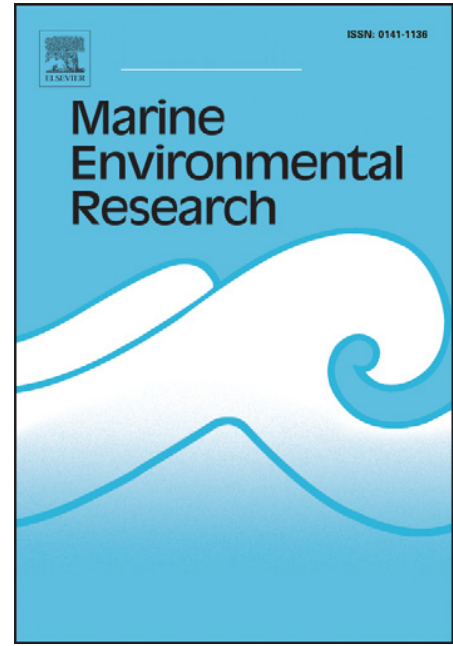

To appear in:

Marine Environmental Research

Received Date:

16 June 2008

Revised Date:

19 March 2009

Accepted Date:

9 June 2009

Please cite this article as: Frías-Espericueta, M.G., Voltolina-Lobina, D., Osuna-López, I., Izaguirre-Fierro, G., Toxicity of metal mixtures to the Pacific white shrimp Litopenaeus vannamei postlarvae, Marine Environmental Research (2009), doi: 10.1016/j.marenvres.2009.06.011

This is a PDF file of an unedited manuscript that has been accepted for publication. As a service to our customers we are providing this early version of the manuscript. The manuscript will undergo copyediting, typesetting, and review of the resulting proof before it is published in its final form. Please note that during the production process errors may be discovered which could affect the content, and all legal disclaimers that apply to the journal pertain. 
1 Toxicity of metal mixtures to the Pacific white shrimp Litopenaeus vannamei

2 postlarvae

3 M.G. Frías-Espericueta ${ }^{\mathrm{a}}$, D. Voltolina-Lobina ${ }^{\mathrm{b}} *$, I. Osuna-López ${ }^{\mathrm{a}}$, G. Izaguirre-Fierro $^{\mathrm{a}}$

4

$5{ }^{a}$ Autonomous University of Sinaloa, Faculty of Marine Science, Environmental Studies

6 Laboratory, P.O. Box 1132, Mazatlán, Sinaloa 82000, México.

$7{ }^{\mathrm{b}}$ Center of Biological Research of the North West, UAS-CIBNOR Laboratory, P.O. Box

8 1132, Mazatlán Sinaloa, 82000, México (e-mail: voltolin04@cibnor.mx)

9

10 Abstract

11 According to the literature, the safe level of a toxic substance for any given organism

12 may be calculated from its median lethal concentration multiplied by a suitable

13 application factor (AF: usually 0.1 and 0.01 ). The medial lethal concentrations for

14 Litopenaeus vannamei postlarvae exposed to the mixtures in equitoxic proportions of

$15 \mathrm{Cd}-\mathrm{Hg}, \mathrm{Hg}-\mathrm{Zn}$ and $\mathrm{Hg}-\mathrm{Pb}$ were close to one order of magnitude lower than the values

16 calculated from individual toxicity tests, indicating a synergistic effect, while the

17 mixture $\mathrm{Cd}-\mathrm{Zn}$ showed an antagonistic effect. Exposure to the mixture of $\mathrm{Cu}, \mathrm{Fe}, \mathrm{Mn}$,

$18 \mathrm{Zn}, \mathrm{Cd}, \mathrm{Hg}$ and $\mathrm{Pb}$ caused 63.3 and $100 \%$ mortality after 21 and 13 days for 0.05 and

$19 \quad 0.1 \mathrm{AF}$, showing that environmentally safe concentrations of toxicants should not be

20 calculated from individual toxicity tests.

22 Keywords: Toxicity; Safe level; Metal mixtures; Litopenaeus vannamei 


\section{ACCEPTED MANUSCRIPT}

\section{1. Introduction}

25 Continental waters discharge into the marine environment the different substances they

26 receive from anthropogenic and natural sources; in most situations these discharges

27 contain complex mixtures, which are likely to cause environmental damage because

28 mixtures of toxicants in concentrations below their individual toxic levels may have

29 negative effects on the growth and reproduction of aquatic organisms (Enserink et al.,

30 1991; Barata et al., 2006).

31 There is evidence that the levels of heavy metals are increasing throughout northern

32 Mexico (Holguín et al., 2006), especially in the coastal waters and lagoons of the

33 Pacific NW which receive industrial, agricultural and municipal wastewaters and their

34 accompanying contaminants. In one coastal lagoon, Soto-Jiménez et al. (2003)

35 calculated yearly anthropogenic inputs of 350, 1020 and $970 \mathrm{~kg}$ of $\mathrm{Cd}, \mathrm{Cu}$ and $\mathrm{Zn}$, and

36 Frías-Espericueta et al. (2005) reported concentrations of 1.1-6 $\mu \mathrm{g} / \mathrm{g}$ of Cd, 33.8-110 of

$37 \mathrm{Cu}, 6.4-19.4$ of $\mathrm{Pb}$ and $1146-2531$ of $\mathrm{Zn}$ in aquatic organisms of the NW coast of

38 Mexico. Therefore, these discharges may become a major threat to the ecology and to

39 the traditional fishery of the coastal states of NW Mexico, as well as to their growing

40 shrimp culture industry (Páez-Osuna et al., 2003).

41 Metals may affect the metabolism of penaeid shrimp: for instance, exposure to Cd or to

$42 \mathrm{Zn}$ affects the gill functions of Litopenaeus vannamei and L. schmitti (Wu and Chen,

43 2004; Barbieri, 2007), and of Farfantepenaeus brasiliensis challenged with sublethal

44 levels of $\mathrm{Hg}$ (Barbieri et al., 2005). 
However, there is scant information concerning the toxicity of metal mixtures for the white shrimp Litopenaeus vannamei, which is the most important species for Mexican aquaculture. The purpose of this study was to assess the effects of mixtures of some essential $(\mathrm{Cu}, \mathrm{Fe}, \mathrm{Mn}$ and $\mathrm{Zn})$ and non essential $(\mathrm{Cd}, \mathrm{Hg}$ and $\mathrm{Pb})$ metals on mortality, feeding and growth of postlarvae of the Pacific white shrimp L. vannamei.

\section{Materials and Methods}

\subsection{Toxicity ratios, toxic unit and application factors calculations}

The safe level of a toxic substance (concentration which presumably has no sublethal or chronic effect), may be predicted multiplying its median lethal concentration (usually 96-h LC50) by a suitable application factor (AF: usually 0.1 and 0.01) (Buikema et al., 1982; Mariño-Balsa et al., 2000).

The 96-h LC50 of $\mathrm{Cd}, \mathrm{Cu}, \mathrm{Fe}, \mathrm{Hg}, \mathrm{Mn}, \mathrm{Pb}$ and $\mathrm{Zn}$ for L. vannamei postlarvae were calculated with a computer program based on Probit analysis (Finney, 1971), using the results results of previous experiments (Frías-Espericueta et al., 2001, 2003). The individual 96-h LC50 values were used to calculate the nominal equitoxic concentrations of the experimental mixtures for the application factors $0.1,0.05,0.025$ and 0.01 (Table 1).

The individual stock solutions were prepared in MilliQ deionized water with concentrations equivalent to the $96-\mathrm{h} \mathrm{LC} 50$ of the water-soluble salts $\mathrm{CdCl}_{2}, \mathrm{CuCl}_{2}$, $\mathrm{FeCl} 3 \bullet 6 \mathrm{H}_{2} \mathrm{O}, \mathrm{HgCl}_{2}, \mathrm{MnCl}_{2} \bullet 4 \mathrm{H}_{2} \mathrm{O}, \mathrm{PbCl}_{2}$ and $\mathrm{ZnCl}_{2}$; the nominal test concentrations of each metal were obtained adding appropriate aliquots of each stock solution to the 
67 shrimp culture water. These salts react with seawater (mainly with $\mathrm{Cl}^{-}$and $\mathrm{OH}^{-}$), and 68 generate $\mathrm{CdCl}_{2}, \mathrm{Cu}(\mathrm{OH})_{2}, \mathrm{FeOH}, \mathrm{HgCl}$ and $\mathrm{PbCO}_{3}$ as the dominant chemical species for

$69 \mathrm{Cd}, \mathrm{Cu}, \mathrm{Fe}, \mathrm{Hg}$ and $\mathrm{Pb}$, whereas the free ion is dominant in the case of $\mathrm{Mn}$ and $\mathrm{Zn}$

70 (Mantoura et al., 1978; Hall et al., 1995).

71 In one first experiment, which lasted one week (168 h), we used the binary mixtures Cd-

$72 \mathrm{Hg}, \mathrm{Cd}-\mathrm{Zn}, \mathrm{Hg}-\mathrm{Zn}$ and $\mathrm{Hg}-\mathrm{Pb}$ with a 1:1 toxicity ratio (TR), and the experiment was

73 carried out for different toxic units (TU), calculated with the equations:

74

75

76

77

78

$$
\mathrm{TR}=\mathrm{M} 1-\mathrm{m} / \mathrm{LC} 50 \mathrm{M} 1: \mathrm{M} 2-\mathrm{m} / \mathrm{LC} 50 \mathrm{M} 2
$$

and

$$
\mathrm{TU}=(\mathrm{M} 1-\mathrm{m} / \mathrm{LC} 50 \mathrm{M} 1)+(\mathrm{M} 2-\mathrm{m} / \mathrm{LC} 50 \mathrm{M} 2)
$$

M1-m and M2-m are the concentrations in the mixture of metals M1 and M2, and LC50 M1 and LC50 M2 their respective 96-h LC50 (Logan and Wilson, 1995).

The effect of any given binary metal mixture was determined from the sum of toxic contributions (S) calculated as:

$$
\mathrm{S}=([\mathrm{A}] / \mathrm{LC} 50 \mathrm{M} 1)+([\mathrm{B}]) / \mathrm{LC} 50 \mathrm{M} 2)
$$

Where $[\mathrm{A}]$ and $[\mathrm{B}]$ are the concentrations of each metal in the mixture causing $50 \%$ mortality. $\mathrm{S}$ values $<1,=1$, or $>1$ were taken as proof of synergism, simple additivity or antagonism, respectively (Vermeulen, 1995).

In the second experiment the design was similar and the AFs were the same, but the organisms were exposed to the mixture of the seven metals and the exposure lasted 21 days.

\subsection{Acclimation and water characteristics}


89 For each experiment, we used postlarvae (PL12) of L. vannamei $(1.2 \pm 0.2 \mathrm{~cm})$ obtained 90 at different times and of different parental origin from a local commercial hatchery. The

91 postlarvae were acclimated during three days to the experimental conditions in a 92 common 501 container with natural seawater, previously filtered through a sand and 93 gravel bed, one cartridge system (10 to $1 \mu \mathrm{m})$ and treated with $0.5-\mu \mathrm{m}$ mesh activated 94 charcoal. The water was renewed daily and the postlarvae, kept with a 12:12-h 95 light:dark photoperiod, were fed ad libitum freshly hatched Artemia sp. nauplii supplied 96 twice daily in equal rations (Frías-Espericueta et al., 2003).

97 After this first period of acclimation, triplicate groups of 10 postlarvae for each

98 experimental treatment, taken at random from the common tank, were placed in $600 \mathrm{ml}$

99 acid-washed glass beakers with $300 \mathrm{ml}$ of filtered seawater aerated with an airstone,

100 where they were kept for three additional days under the same conditions.

101 Throughout this period and during the experiment, the mean background concentrations

102 of $\mathrm{Cd}, \mathrm{Cu}, \mathrm{Fe}, \mathrm{Mn}, \mathrm{Pb}$ and $\mathrm{Zn}$, determined by atomic absorption spectrophotometry

103 (Spectra AA Varian), were $0.35,8.0,1.6,1.5,1.1$ and $6.7 \mu \mathrm{g} / \mathrm{l}$, respectively.

104 Temperature was maintained nearly constant at $29 \pm 0.5^{\circ} \mathrm{C}$ and the mean values of 105 salinity was $35.4 \pm 0.2 \mathrm{ppt}$. The ranges of the chemical characteristics of the seawater 106 used for the experiments are given in Table 2.

107 It is generally accepted that the toxicity of metals is inversely related to ambient salinity

108 (Hall et al., 1995). However, although in Mexican shrimp farms L. vannamei may be 109 grown at salinities ranging from $<1$ to $50 \mathrm{ppt}$, all commercial shrimp hatcheries of the

110 Mexican NW use full strength seawater with a salinity close to that of this study, 
111 because they are located in the marine coastal zone where the most common salinity

112 values range between 37 and 35 ppt (Cano-Pérez, 1991).

$113 \quad 2.3$ Exposure experiments

114 After this period, each group of three beakers was added the respective metal mixture;

115 in all cases the experimental conditions were the same as during the acclimation period,

116 but the test solutions were renewed every $48 \mathrm{~h}$ and the organisms were fed individual

117 daily rations of 20 Artemia nauplii, supplied every 12 hours in equal portions.

118 In both experiments, observations on survival and molting were carried out at 12-h

119 intervals in each container. Death was assumed in absence of response to a mechanical

120 stimulus with a glass rod. The food consumption in each test solution during the second

121 experiment was calculated by difference between the nauplii supplied daily to each

122 container and those remaining in the flask 24 hours later.

124 3. Results

$125 \quad 3.1$ Mortality

126 Previous experiments with L. vannamei postlarvae showed that $\mathrm{Hg}$ and $\mathrm{Zn}$ are the most

127 toxic among the metals used in this work (Frías-Espericueta et al., 2001, 2003). This

128 was confirmed by the results of the first experiment, since the lowest $\mathrm{TU}_{50}$ was

129 observed with the $\mathrm{Hg}-\mathrm{Zn}$ binary mixture.

130 The TU50 values of each binary mixture decreased with the time of exposure (Table 3),

131 the three mixtures $\mathrm{Cd}-\mathrm{Hg}, \mathrm{Hg}-\mathrm{Zn}$ and $\mathrm{Hg}-\mathrm{Pb}$ caused $50 \%$ mortalities at metal

132 concentrations close to one order of magnitude lower than their individual 96-h LC50, 
133 and the respective sums of toxic contributions were $<1(\mathrm{~S}=0.21,0.16$ and 0.22 for $\mathrm{Cd}-$

$134 \mathrm{Hg}, \mathrm{Hg}-\mathrm{Zn}$ and $\mathrm{Hg}-\mathrm{Pb}$, respectively). This indicates a synergistic effect, whereas the

135 mixture $\mathrm{Cd}-\mathrm{Zn}$ showed an antagonistic effect $(\mathrm{S}=2.58)$.

136 In the second experiment with the mixture of the seven metals, survival was $100 \%$ in

137 the control cultures and in those exposed to 0.01 and $0.025 \mathrm{AF}$, whereas mortality was

13863.3 and $100 \%$ after 21 and 13 days for those exposed to 0.05 and $0.1 \mathrm{AF}$, respectively

139 (Table 4).

$140 \quad 3.2$ Food consumption, molting and growth

141 In the second, multi-metal exposure experiment, there was no significant correlation

142 between instant mortality and ecdysis ( $\mathrm{P}>0.1$ in all cases). However, we noticed a

143 decreasing number of exuviae with increasing AF, as well as a progressive decrease of

144 the final mean weights of the postlarvae, which were significantly $(\mathrm{p}<0.05)$ lower

145 with 0.025 and $0.05 \mathrm{AF}$ than in the control cultures and in those exposed to $0.01 \mathrm{AF}$

146 (one-way ANOVA and Tukey's multiple comparison tests, $\alpha=0.05$ ) (Table 4).

147 There were no significant differences between the food consumption observed in the

148 cultures exposed to 0.01 and $0.025 \mathrm{AF}$ and those of the control. The mortality in the

149 cultures exposed to 0.05 and $0.1 \mathrm{AF}$ did not allow a meaningful comparison with the

150 rest of the treatments.

\section{4. Discussion}

152 The antagonistic effect of $\mathrm{Cd}$ and $\mathrm{Zn}$ coincides with the protective effect of $\mathrm{Zn}$ noticed

153 in the mysid Praunus flexuosus challeged with a mixture of metals (McLusky and

154 Hagerman, 1987), and with the results of Barata et al. (2006) who pointed out that, 
155 since $\mathrm{Zn}, \mathrm{Cu}$ and $\mathrm{Cd}$ are inducers of metallothionein synthesis, there is a high

156 probability of competition for binding sites, and that for this reason their combined

157 effects may be expected to be antagonistic.

158 According to Brzóska and Moniuszko-Jakoniuk (2001), since many toxic effects of Cd

159 result from interactions with essential metals, including $\mathrm{Zn}$, the availability of $\mathrm{Zn}$ is an

160 important factor with respect to Cd toxicity. While exposure to $\mathrm{Cd}$ interferes with the

$161 \mathrm{Zn}$ biological functions, dietary $\mathrm{Zn}$ intake affects $\mathrm{Cd}$ absorption and accumulation, and

162 prevents or at least reduces its adverse effects.

163 A similar antagonistic effect of $\mathrm{Cu}$ and $\mathrm{Zn}$ was observed in L. vannamei and Daphnia

164 magna by Frías-Espericueta et al. (2003) and by Cañizares-Villanueva et al. (2000),

165 although Negilski et al. (1981) and Vanegas et al. (1997) found a synergistic effect in

166 the crustaceans Callianassa australiensis and Litopenaeus setiferus exposed to a

167 mixture Cd-Zn, which could be explained by genetic differences or by different

168 chemical characteristics of the respective aquatic environments.

169 The synergism of the mixture $\mathrm{Cd}$ and $\mathrm{Hg}$ was observed in the mussel Perna viridis by

170 Mohan et al. (1986). Both metals have a high affinity for protein binding sites, which

171 might explain their increased toxicity when they occur at relatively high concentrations

172 in the environment (Barata et al., 2006). A similar explanation is likely for the increased

173 toxicity of the mixtures $\mathrm{Hg}-\mathrm{Zn}$ and $\mathrm{Hg}-\mathrm{Pb}$, although we could not trace other studies on

174 the interactive effect of these metals.

175 The mortalities of $L$. vannamei observed in the mixture of the seven metals agree with

176 those observed by Chu and Chow (2002) and Verslycke et al. (2003), when the 


\section{ACCEPTED MANUSCRIPT}

177 nematode Caenorhabditis elegans and the crustacean Neomysis integer were exposed to

178 combinations of metals in concentrations deemed to be individually safe. These results

179 confirm that metal interactions must not be neglected, since even if they are present in

180 minute amounts, their interactions may generate a severe environmental stress.

181 When L. vannamei are exposed to metals, these are accumulated in gill tissues (Wu and

182 Chen,2004) and cause cytological and histochemical damage to the gill epithelium. The

183 resulting alterations in gill functions and inhibition of oxygen consumption (Soegianto

184 et al., 1999a,b; Barbieri, 2009) could explain the mortalities observed in this study.

185 Wong et al. (1993) found that metal exposure of Metapenaeus ensis postlarvae affects

186 their rate of predation and consumption of Artemia nauplii, and Barata and Baird (2000)

187 observed that $\mathrm{Cd}$ and $\mathrm{Cu}$ strongly impair feeding of Daphnia magna. Although our

188 results do not confirm that food consumption of L. vannamei postlarvae is a good

189 indicator of metal stress, their reduced growth coincides with that observed in

190 Ceriodaphnia dubia and Daphnia magna exposed to metal mixtures, and in this case it

191 could be due to a greater energy allocation to protect cells from metal accumulation and

192 toxic effects (Spehar and Fiandt, 1986; Enserink et al., 1991).

193 The presence of metals in Mexican coastal waters should be of concern for commercial

194 hatcheries, because it may result in alterations of different metabolic functions, such as

195 those observed in different penaeid shrimps exposed to metals alone (Soegianto et al.

196 1999a,b; Barbieri, 2007, 2009) or in mixtures (Wu and Chen,2004). It should also be of

197 environmental concern, because metals cause increased susceptibility to other stressors

198 in aquatic organisms (Liao et al., 2006). 
199 Some authors have pointed out that it is difficult to extrapolate laboratory results to the

200 natural environment, because other variables ( $\mathrm{pH}$, alkalinity, natural chelators,

201 temperature and salinity, among others) may affect the response of aquatic organims

202 modifying the availability as well as the toxicity of metals (Wong et al., 1993; Wu and

203 Chen, 2004).

204 The results of several authors indicate that L. vannamei is a good test organisms for

205 laboratory experiments on the effects of heavy metals, but there is insufficient evidence

206 that it could be used for the in situ assessment of water pollution in field conditions.

207 Although our results indicate that $0.01 \mathrm{AF}$ is a safe level for the survival of shrimp

208 postlarvae, those of other authors indicate metabolic dysfunctions when metals are

209 present at sublethal levels, which might have a severe effect in the long term. Therefore,

210 we feel that additional observations on the histological and biochemical effects of

211 sublethal concentrations of metals should be used to validate our result.

212 We also feel that the allowable concentrations of toxic substances for regulatory use

213 should not be based on untested hypothesis and that, since different species may show

214 different responses (Spehar and Fiandt, 1986), any allowable limit may be too

215 permissive to protect some species when other toxicants are also present.

217 Acknowledgments.

218 Supported by CONACYT and CIBNOR projects 32501-T and AC1.4. The authors

219 thank M.A. Herrera-Vega, G. Barrón-Gallardo and H. Bojórquez-Leyva for technical 220 assistance. 


\section{References}

223 Barata, C., Baird, D.J., 2000. Determining the ecotoxicological mode of actions of

224 toxicants from measurements on individuals: results from short duration chronic test 225 with Daphnia magna Straus. Aquatic Toxicology 48, 195-209.

226

227 Barata, C., Baird, D.J., Nogueira, A.J.A., Soares, A.M.V.M., Riva, M.C., 2006.

228 Toxicity of binary mixtures of metals and pyrethroid insecticides to Daphnia magna

229 Straus. Implications for multi-substance risks assessment. Aquatic Toxicology 78, 1-14. 230

231 Barbieri, E., 2007. Use of oxygen consumption and ammonium excretion to evaluate 232 the sublethal toxicity of cadmium and zinc on Litopenaeus schmitti (Burkenroad, 1936,

233 Crustacea). Water Environment Research 79, 641-646.

235 Barbieri, E., 2009. Effects of zinc and cadmium on oxygen consumption and 236 ammonium excretion in pink shrimp (Farfantepenaeus paulensis, Pérez-Farfante, 1967,

237 Crustacea). Ecotoxicology 18, 312-318.

239 Barbieri, E., Passos, E.A., García, C.A.B., 2005. Use of metabolism to evaluate the 240 sublethal toxicity of mercury on Farfantepenaeus brasiliensisi larvae (Latreille 1817, 241 Crustacean). Journal of Shellfish Research 24, 1229-1233. 
243 Brzóska, M.M., Moniuszko-Jakoniuk, J., 2001. Interactions between cadmium and zinc

244 in the organism. Food Chemistry and Toxicology 39, 967-980.

245

246 Buikema, A.L., Niederlehner, B.R., Cairns, J.Jr., 1982. Biological monitoring. Part IV.

247 Toxicity treating. Water Research 16, 239-262.

248

249 Cano-Pérez, F.A. 1991. Golfo de California. Oceanografía física, in: De la Lanza-

250 Espino, G., Oceanografía de los Mares Mexicanos, AGT Editor, Mexico, D.F. pp. 453251514.

252

253 Cañizares-Villanueva, R.O., Martínez-Córdova, F., Espinoza-Chavez, F., 2000. Acute

254 toxicity to Daphnia magna of effluents containing $\mathrm{Cd}, \mathrm{Zn}$ and a mixture $\mathrm{Cd}-\mathrm{Zn}$ after

255 metal removal by C. vulgaris. Environmental Toxicology 15, 160-164.

256

257 Chu, K.W., Chow, K.L., 2002. Synergistic toxicity of multiple heavy metals is revealed 258 by a biological assay using a nematode and its transgenic derivate. Aquatic Toxicology $259 \quad 61,53-64$.

261 Enserink, E.L., Mass-Diepeveen, J.L., Van Leeuwen, C.J., 1991. Combined effects of 262 metals: an ecotoxicological evaluation. Water Research 25, 679-687.

263 Finney, D.J., 1971. Probit Analysis. $3^{\text {rd }}$ edition. Cambridge University Press, London. 264 
265 Frías-Espericueta, M.G., Voltolina, D., Osuna-López, J.I., 2001. Acute toxicity of Cd, Hg

266 and $\mathrm{Pb}$ to whiteleg shrimp Litopenaeus vannamei postlarvae. Bulletin of Environmental

267 Contamination and Toxicology 67, 580-586.

268

269 Frías-Espericueta, M.G., Voltolina, D., Osuna-López, J.I., 2003. Acute toxicity of copper,

270 zinc, iron and manganese and of the mixtures copper-zinc and iron-manganese to whiteleg

271 shrimp Litopenaeus vannamei postlarvae. Bulletin of Environmental Contamination and

272 Toxicology 71, 68-74.

273

274 Frías-Espericueta, M.G., Osuna-López, J.I., Estrada-Toledo, F.J., López-López, G.,

275 Izaguirre-Fierro, G., 2005. Heavy metals in the edible muscle of shrimps from several

276 coastal lagoons located in the NW of Mexico. Bulletin of Environmental Contamination

277 and Toxicology 74, 1098-1104.

278

279 Hall, Jr.L.W., Ziegenfuss, M.C., Anderson, R.D., Lewis, B.L., 1995. The effect of

280 salinity on the acute toxicity of total and free cadmium to a Chesapeake Bay copepod

281 and fish. Marine Pollution Bulletin 30, 376-384.

282

283 Holguín, C., Rubio, H., Olave, M.E., Saucedo, R., Gutiérrez, M., Bautista, R., 2006.

284 Calidad del agua del Río Conchos en la región de Ojinaga, Chihuahua: parámetros

285 fisicoquímicos, metales y metaloides. Universidad y Ciencia 22, 51-63. 
Liao, C.M., Chang, C.F., Yeh, C.H., Chen, S.C., Chiang, K.C., Chio, C.P., Chou, B.Y.H., Jou, L.J., Lien, G.W., Lin, C.M., Shen, H.H., Wu, G.D., 2006. Metal stresses affect the population dynamics of disease transmission in aquaculture species. Aquaculture 257, 321-332.

291

292 Logan, D.T., Wilson, H.T., 1995. An ecological risk assessment method for species 293 exposed to contaminant mixtures. Environmental Toxicology and Chemistry 14, 51294359.

Mantoura, R.F.C., Dickson, A., Riley, J.P., 1978. The complexation of metals with humic materials in natural waters. Estuarine, Coastal and Marine Science 6, 378-408.

300 dissolved metals to early larval stages of Palaemon serratus, Maja squinado and

301 Homarus gammarus (Crustacea: Decapoda). Archives of Environmental Contamination 302 and Toxicology 39, 345-351.

303

304 McLusky, D.S., Hagerman, L., 1987. The toxicity of chromium, nickel and zinc: effects 305 of salinity and temperature, and the osmoregulatory consecuences in the mysid Praunus 306 flexuosus. Aquatic Toxicology 10, 225-238. 
308 Mohan, C.V., Gupta, T.R.C., Shelly, H.P.C., Menon, M., 1986. Combined toxicity of Hg

309 and Cd to the mussel Perna viridis. Diseases of Aquatic Organisms 2, 65-72.

310

311 Negilski, D.S., Ahsanullah, M., Mobley, M.C., 1981. Toxicity of Zn, Cd and Cu to the

312 shrimp Callianassa australiensis. Marine Biology 64, 305-309.

313

314 Páez-Osuna, F., Gracia, A., Flores-Verdugo, F., Lyle-Fritch, L.P., Alonso-Rodríguez,

315 R., Roque, A., Ruiz-Fernández, A.C., 2003. Shrimp aquaculture development and the

316 environment in the Gulf of California ecoregion. Marine Pollution Bulletin 46, 806-

317815.

318

319 Soegianto, A., Charmantier-Daures, M., Trilles, J.P., Charmantier, G., 1999a. Impact of

320 cadmium on the structure of gills and epipodites of the shrimp Penaeus japonicus

321 (Crustacea:Decapoda). Aquatic Living Resources 12, 57-70.

322

323 Soegianto, A., Charmantier-Daures, M., Trilles, J.P., Charmantier, G., 1999b. Impact of

324 copper on the structure of gills and epipodites of the shrimp Penaeus japonicus. Journal

325 of Crustacean Biology 19, 209-223.

326

327 Soto-Jiménez, M.F., Páez-Osuna, F., Ruiz-Fernández, A.C., 2003. Geochemical

328 evidences of the anthropogenic alteration of trace metal concentrations of the sediments

329 of Chiricaueto marsh (SE Gulf of California). Environmental Pollution 125, 423-432. 
331 Spehar, R.L., Fiandt, J.T., 1986. Acute and chronic effects of water quality criteria-

332 based metal mixtures on three aquatic species. Environmental Toxicology and

333 Chemistry 5, 917-931.

334

335 Vanegas, C., Espina, S., Botello, A.V., Villanueva, S., 1997. Acute toxicity and

336 synergism of $\mathrm{Cd}$ and $\mathrm{Zn}$ in the white shrimp Penaeus setiferus juveniles. Bulletin of

337 Environmental Contamination and Toxicology 58, 87-92.

338

339 Vermeulen, A.C., 1995. Elaborating chironomid deformities as bioindicator of toxic

340 sediments stress: the potential application of mixture toxicity concepts. Annales

341 Zoologici Fennici 32, 265-285.

343 Verslycke, T., Vangheluwe, M., Heijerick, D., De Schamphelaere, K., Van Sprang, P.,

344 Janssen, C.R., 2003. The toxicity of metal mixtures to the estuarine mysid Neomysis

345 integer (Crustacea: Mysidacea) under changing salinity. Aquatic Toxicology 64, 307-

346315.

347

348 Wong, C.K., Chu, K.H., Tang, K.W., Tam, T.W., Wong, L.J., 1993. Effects of

349 chromium, copper and nickel on survival and feeding behavior of Metapenaeus ensis

350 larvae and postlarvae (Decapoda: Penaeidae). Marine Environmental Research 36, 63-

35178. 
353 Wu, J.P., Chen, H.C., 2004. Effects of cadmium and zinc on oxigen consumption,

354 ammonium excretion, and osmoregulation on white shrimp (Litopenaeus vannamei).

355 Chemosphere 57, 1591-1598.

356

357

358 


\section{ACCEPTED MANUSCRIPT}

359 Table 1. Median lethal concentrations (96-h LC50) and respective nominal equitoxic

360 concentrations for each application factor (AF). All values in $\mu \mathrm{g} / \mathrm{l}$.

361

362

\begin{tabular}{cccccc}
\hline \multirow{2}{*}{ Metal } & \multirow{2}{*}{96 -h LC50* } & \multicolumn{4}{c}{ AF } \\
& & 0.01 & 0.025 & 0.05 & 0.1 \\
\hline $\mathrm{Cd}$ & 2490 & 24.9 & 62.25 & 124.5 & 249 \\
$\mathrm{Cu}$ & 37300 & 373 & 932.5 & 865 & 3730 \\
$\mathrm{Fe}$ & 44200 & 442 & 1105 & 2210 & 4420 \\
$\mathrm{Hg}$ & 1230 & 12.3 & 30.75 & 61.5 & 123 \\
$\mathrm{Mn}$ & 130000 & 1300 & 3250 & 6500 & 13000 \\
$\mathrm{~Pb}$ & 134000 & 1340 & 3350 & 6700 & 13400 \\
$\mathrm{Zn}$ & 2080 & 20.8 & 52 & 104 & 208 \\
\hline
\end{tabular}

*Frias-Espericueta et al. $(2001,2003)$

363

364

365

366

367

368

369

370

371

372

373

374

375

376 
377 Table 2. Chemical characteristics (ranges) of the seawater used in experiments.

\begin{tabular}{lc}
\hline \multicolumn{1}{c}{ Variable } & $\begin{array}{c}\text { Dissolved } \\
\text { metals }(\mu \mathrm{g} / \mathrm{l})\end{array}$ \\
\hline Temperature: $28-30{ }^{\circ} \mathrm{C}$ & $\mathrm{Cd}: 0.3-0.4$ \\
Salinity: $34-36 \mathrm{ppt}$ & $\mathrm{Cu}: 6.0-8.0$ \\
pH: $8.0-8.1$ & $\mathrm{Fe}: 1.5-2.6$ \\
Oxygen: $5.2-5.8 \mathrm{mg} / \mathrm{l}$ & $\mathrm{Mn}: 1.3-2.2$ \\
Total alkalinity: $2.10-2.13 \mathrm{meq} / \mathrm{l}$ & $\mathrm{Pb}: 1.0-1.1$ \\
Ammonia-N: $9.0-13.0$ & $\mathrm{Zn}: 1.9-2.9$ \\
Nitrite-N: $3.9-5.2 \mu \mathrm{g} / \mathrm{l}$ & \\
Nitrate-N: $220-280 \mu \mathrm{g} / 1$ & \\
Phosphate-P: $68-80 \mu \mathrm{g} / 1$ & \\
\hline
\end{tabular}

378

379

380

381

382

383

384

385

386

387

388

389

390

391

392 
393 Table 3 . TU50 values (in parenthesis, 95\% confidence limits) of binary metal mixtures 394 for Litopenaeus vannamei postlarvae.

395

\begin{tabular}{cccccc}
\hline $\begin{array}{c}\text { Exposure } \\
\text { time (h) }\end{array}$ & TU50 & $\begin{array}{c}\text { TU50 of mixtures } \\
\text { Equivalent } \\
\text { concentrations in the } \\
\text { mixture }\end{array}$ & $\begin{array}{c}\text { Individual 96-h LC50 } \\
(\mathrm{mg} / \mathrm{l})^{*}\end{array}$ \\
\hline & & $\mathrm{Cd}$ & $\mathrm{Hg}$ & $\mathrm{Cd}$ & $\mathrm{Hg}$ \\
96 & $0.22(0.19,0.26)$ & 0.27 & 0.13 & 2.49 & 1.23 \\
168 & $0.19(0.16,0.22)$ & 0.23 & 0.11 & & $\mathrm{Zn}$ \\
& & $\mathrm{Cd}$ & $\mathrm{Zn}$ & $\mathrm{Cd}$ & 2.08 \\
96 & $2.60(2.40,2.80)$ & 3.23 & 2.70 & 2.49 & $\mathrm{Zn}$ \\
168 & $2.12(1.88,2.33)$ & 2.63 & 2.20 & & 2.08 \\
96 & $0.17(0.15,0.19)$ & 0.10 & 0.17 & 1.23 & $\mathrm{~Pb}$ \\
168 & $0.14(0.12,0.15)$ & 0.08 & 0.14 & $\mathrm{Hg}$ & 134.2 \\
96 & $0.23(0.19,0.27)$ & 0.14 & 15.40 & 1.23 & \\
168 & $0.20(0.17,0.23)$ & 0.12 & 13.40 & & $\mathrm{Hg}$ \\
\hline
\end{tabular}

396 *Frias-Espericueta et al. $(2001,2003)$

397

398

399

400

401

402

403

404

405

406 
407 Table 4. Survival (\%), number of exuviae, final weight (W, in $\mathrm{mg}$ ) and food 408 consumption (FC in \% of control) of L. vannamei postlarvae exposed to different 409 application factors. Different letters indicate significant difference $(\alpha=0.05)$.

410

411

\begin{tabular}{ccccc}
\hline AF & $\begin{array}{c}\text { Survival } \\
\%\end{array}$ & $\begin{array}{c}\text { Exuviae } \\
(\mathrm{N})\end{array}$ & $\mathrm{W}$ & $\mathrm{FC}(\%)$ \\
\hline control & 100 & 98 & $18.2 \pm 5.3^{\mathrm{a}}$ & 100 \\
0.01 & 100 & 88 & $13.1 \pm 4.9^{\mathrm{a}}$ & 100 \\
0.025 & 100 & 47 & $8.3 \pm 1.7^{\mathrm{b}}$ & 97.6 \\
0.05 & 37 & 57 & $4.0 \pm 1.1^{\mathrm{c}}$ & -- \\
0.1 & $0^{*}$ & $17^{*}$ & & -- \\
\hline
\end{tabular}

412

$* 100 \%$ mortality after 13 days of exposure 